УДК 616.155.321:612.112.3+612.112.91)-092.9-08

\title{
Б.М. Вервега
}

\section{ПРОЦЕСИ ФАГОЦИТОЗУ ПРИ АНТИГЕННОМУ НАВАНТАЖЕННІ ТА ЇХ КОРЕКЦІЯ}

Львівський національний медичний університет імені Данила Галицького

Резюме. На експериментальному матеріалі проведено аналіз змін кисневозалежних та кисневонезалежних ферментативних процесів у нейтрофільних гранулоцитах (НГ) щурів, яким змодельовано хронічний імунокомплексний процес (XIКП) з корекцією плацентарним полібіоліном. Встановлено, що в умовах ХІКП активуються ферментативні процеси в НГ. При застосуванні плацентарного полібіоліну відновлюється захоп- лювальна здатність та знижується активність кисневозалежних та кисневонезалежних ферментативних процесів НГ, що, у свою чергу, призводить до нормалізації інтеграційних процесів.

Ключові слова: хронічний імунокомплексний процес, нейтрофільні гранулоцити, фагоцитарні процеси.

Для відтворення моделі хронічної сироваткової хвороби обрали модель, запропоновану Cochrane C.G. у модифікації Wilson C.B. et al. (1976), яка викликається уведенням кожних сім днів протягом 12 тижнів у хвостову вену щура бичачого сироваткового альбуміну із розрахунку 100 мг/кг маси. Оскільки в картині хронічної сироваткової хвороби провідним $є$ збільшення рівня циркулюючих імунних комплексів (ЦІК) у крові, за їх рівнем судили про ступінь розвитку хвороби. Плацентарний полібіолін уводився в разовій дозі 5 мг/100г курсом 10 днів. Фагоцитарну активність нейтрофілів периферичної крові вивчали за загальноприйнятими методами.

Досліди на тваринах виконувалися 3 дотриманням Європейської конвенції про захист хребетних тварин, які використовують для експериментальних досліджень (Страсбург, 1985). Евтаназію тварин проводили шляхом декапітації при глибокому наркозі, визваному тіопенталом натрію.

Статистичне опрацювання здійснювали за допомогою програми «Statistica 6.0».

Результати дослідження та їх обговорення. Оцінка показників прямих механізмів фагоцитозу, динаміка показників нейтрофілозалежних механізмів фагоцитарної активності за умов ХІКП після уведення тваринам плацентарного полібіоліну представлені в таблиці.

Порівняння результатів досліджень показників фагоцитозу при ХІКП підтверджує, що довготривале антигенне навантаження на організм тварин призводить до дисбалансу окремих ланок фагоцитозу, що проявляється розвитком картини, характерної для ХІКП $[2,4,5,8]$. Даний патологічний процес супроводжувався змінами з боку показників прямих та опосередкованих механізмів фагоцитарної активності НГ. Основні імунопатологічні прояви полягали в підвищеній продукції патогенних ЦІК (табл. 2), активації кисневозалежних та кисневонезалежних ферментативних процесів і захоплення чужорідних частинок у НГ.

Як видно 3 табл. 1, під впливом плацентарного полібіоліну зменшилася абсолютна кількість нейтрофільних фагоцитів на $28 \%$, тоді як відсотковий вміст зовсім не змінився. Плацентарний (10 тварин). 


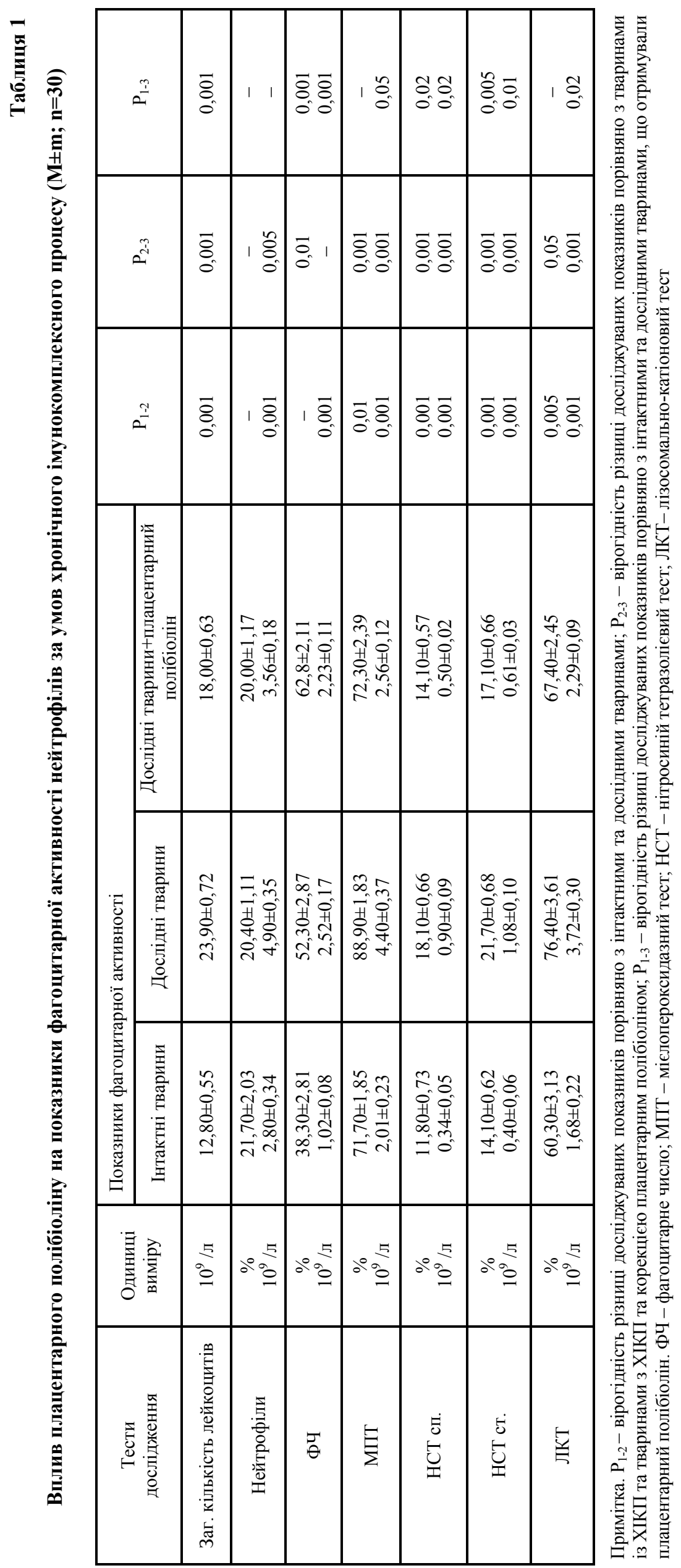


ํㅡㄹ

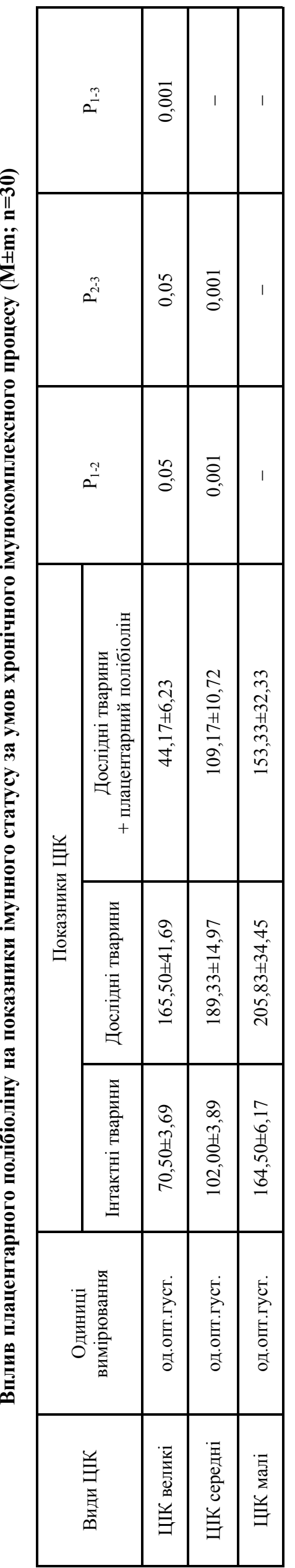

полібіолін активує захоплювальну здатність НГ, про що свідчать збільшення показників латексного тесту на $20 \%$, тоді як абсолютні значення латексного тесту вірогідно не змінюються.

Ферментативні процеси в НГ під впливом плацентарного полібіоліну також зазнали певних змін, що проявилося у зменшенні активності як кисневозалежних ферментативних процесів на 18 \%, так і кисневонезалежних процесів. Про що свідчить зниження показників лізосомальнокатіонового тесту у відносних значеннях на $12 \%$ та в абсолютних значеннях на $39 \%$.

Окисно-відновні процеси в НГ сповільнюються, що проявлясться зниженням показників спонтанного нітросинього тетразолієвого тесту у відсотках на $22 \%$ і в абсолютних значеннях на $46 \%$.

Оцінка показників опосередкованих механізмів фагоцитарної активності нейтрофілів дослідних тварин та динаміка впливу плацентарного полібіоліну на утворення різних типів ЦІК представлена в табл. 2.

Застосування плацентарного полібіоліну викликає зменшення рівня ЦІК усіх розмірів у сироватці крові щурів із ХІКП. Відповідно великі ЦІК достовірно зменшуються на 73 \% порівняно 3 тваринами з ХІКП, котрим не уводили плацентарного полібіоліну, що є менше від цих показників в інтактних тварин. Рівень середніх ЦІК достовірно зменшується на $42 \%$, рівень малих ЦІК має тенденцію до зменшення і відповідає цим показникам в інтактних тварин.

Проведене дослідження показало, що уведення плацентарного полібіоліну тваринам із ХІКП викликає нормалізацію рівня показників ЦІК усіх розмірів.

\section{Висновок}

Одержані результати свідчать, що під впливом плацентарного полібіоліну у тварин із хронічним імунокомплексним процесом відновлюється захоплювальна здатність нейтрофілів та знижується активність кисневозалежних та кисневонезалежних ферментативних процесів нейтрофільних гранулоцитів порівняно з хронічним імунокомплексним процесом, що, у свою чергу, призводить до нормалізації інтеграційних процесів в умовах хронічного імунокомплексного процесу.

Перспективи подальших досліджень направлені на пошук оптимальних доз природного препарату полібіоліну для лікування алергічних захворювань.

\section{Література}

1. Колісник Н.В. Біологія нейтрофілів, сучасний погляд. Огляд / Н.В.Колісник, Ж.С. Качанова // Вісн. Запоріз. нац. у-ту. - 2009. - № 1. - С. 80-91.

2. Литвинець Л.Я. Імунологічні зміни та особливості розвитку запалення при бронхіальній астмі у дітей / Л.Я. Литвинець, О.Б. Синоверська // Здоровье ребенка. - 2011. - № 6. - С. 22-25.

3. Варианты трансформации фенотипа нейтрофильных гранулоцитов $\mathrm{CD} 64^{+} \mathrm{CD} 32^{+} \mathrm{CD} 11 \mathrm{~b}^{+}$у новорожденных c различными инфекционно-воспалительными заболеваниями / И.В Нестерова, Н.В. Колесникова, 
Е.И. Клещенко [та ін.] // Цитокины и воспаление. 2011. - Т. 10, № 4. - С. 61-65.

4. Никитюк Г.П. Електронно-мікроскопічні дослідження та показники ферментативних процесів нейтрофілів за умов довготривалого антигенного навантаження та на тлі введення кверцетину / Г.П. Никитюк, І.М. Лукович, Б.М. Вервега // Мед. транспорту України. 2013. - № 3. - С. 53-57.

5. Чоп'як В.В. Системні васкуліти: патогенез, клініка, лікування / В.В. Чоп`як // Здоров’я України. - 2010. № 3. - C. 76-79.
6. Booth J.W. Membrane dynamics in phagocytosis / J.W. Booth, W.S. Trimble, S. Grinstein // Semin Immunol. - 2001. - Vol. 13. - P. 357-364.

7. Hayashi F. Toll-like receptors stimulate human neutrophil function/ F. Hayashi, T.K Means, A.D. Uster // Blood. 2003. - Vol. 102. - P. 2660-2669.

8. Sohnlein O. Neutrophil granule proteins: modulators of the immune response. Thesis for doctoral degree / Sohnlein O. - Stockcholm, 2008. - $72 \mathrm{p}$.

9. Novel cell death program leads to neutrophil extracellular traps / T.A.Fuchs, U. Abed, C. Goosmann [et al.] // J. Cell Biol. - 2007. - Vol. 176, № 2. - P. 231-241.

\section{ПРОЦЕССЫ ФАГОЦИТОЗА ПРИ АНТИГЕННОЙ НАГРУЗКЕ И ИХ КОРРЕКЦИЯ}

\section{Б.М. Вервега}

Резюме. На экспериментальном материале проведен анализ изменений кислородзависимых и кислороднезависимых ферментативных процессов в нейтрофильных гранулоцитах крыс, которым смоделирован хронический иммунокомплексный процесс с коррекцией плацентарным полибиолином. Установлено, что в условиях хронического иммунокомплексного процесса активируются ферментативные процессы в нейтрофильных гранулоцитах. При применении плацентарного полибиолина восстанавливается захватывающая способность нейтрофильных гранулоцитов и снижается активность кислородзависимых и кислороднезависимых ферментативных процессов в нейтрофильных гранулоцитах, что в свою очередь приводит к нормализации интеграционных процессов.

Ключевые слова: нейтрофильные гранулоциты, хронический иммунокомплексный процесс, фагоцитарные процессы.

\section{THE PROCESS OF PHAGOCYTOSIS IN THE ANTIGENIC LOAD AND THEIR CORRECTION}

\section{B.M. Verveha}

Abstact. Using experimental data an analysis of the changes of the oxygen-dependent and oxygen independent enzymatic processes in neutrophilic granulocytes of rats that had simulated chronic immune complex process with placental polybiolinum correction has been carried out. It was established, that under conditions of chronic immune complex process enzymatic processes in neutrophilic granulocytes get activated. Application of placental polybiolinum restored grasping ability of neutrophils and reduced the activity of the oxygen-dependent and oxygen independent enzymatic processes in neutrophilic granulocytes, which in turn leads to the normalization of the integration processes.

Key words: neutrophil granulocytes, chronic immunocomplex process, phagocytic processes.

The Danylo Halytsky National Medical University in Lviv (Lviv)

Рецензент - проф. І.Й. Сидорчук

Buk. Med. Herald. - 2014. - Vol. 18, № 3 (71). - P. 29-32

Надійшла до редакції 27.05.2014 року

(C) Б.М. Вервега, 2014 